\title{
Relationship Between School Climate and Teachers' Commitment in an Excellent School of Kubang Pasu District, Kedah, Malaysia
}

\section{Arumugam Raman}

Universiti Utara Malaysia

arumugam@uum.edu.my

\section{Chang Chi Ling}

Universiti Utara Malaysia changchiling@hotmail.com

\section{Rozalina Khalid}

Universiti Utara Malaysia

rozalina@uum.edu.my

\section{Doi:10.5901/mjss.2015.v6n3s1p163}

\begin{abstract}
The aim of this study is to identify the relationship between school climate and teachers' commitment. This study focused on five excellent schools in the district of Kubang Pasu, Kedah. The total number of teachers in the five schools was 280 but only 178 teachers were randomly selected to be the respondents. The respondents were asked to complete two sets of questionnaires that are Organizational Climate Index (OCl) from Hoy et al. (2002) to examine school climate while Teachers Organizational Commitment from Celep (2000) to test teachers commitment. Researchers used SPSS version 20.0 to analyze the collected data. Descriptive statistic was used to get the frequency, percentage, mean and standard deviation. Researchers found that the Alpha Cronbach for validity is 0.92. To test school climate with teachers' commitment, descriptive and inferential statistics were used. Data collected was found abnormal (K-S test) so, Spearman Correlation test $p<0.05$ was used. Result showed that school climate has relationship with teachers' commitment. Dimensions such as collaborative leadership, teachers' professional behavior; and working pressure have positive significant relationship with teachers' commitment whereas institutional transparency dimension has no relationship with teachers' commitment. Teachers' professional behavior was deemed as the determinant for teachers' commitment. In conclusion, the result findings of this study can contribute to all types of schools and school administrators. This is because by understanding school climate influence, school administrators and teachers will be able to work towards materializing education excellence at present and for the future.
\end{abstract}

Keywords: school climate, teachers' commitment, excellent school, Sekolah Kebangsaan (primary schools).

\section{Introduction}

Malaysian Education Blueprint (2006-2010) stated that education plays an important role in developing human capital who are knowledgeable and competent, who possess high moral standards, responsible and capable of achieving high levels of personal well- being as well as able to contribute to the harmony and betterment of the family, society and nation at large so as to fulfill the needs for the 2020 nation (MOE, 2006).

The Ministry of Education (MOE) is aware that the development of a nation, unity and economic growth are two important aspects towards transforming Malaysia as high-revenue nation. To ensure that our generation is ready to compete at global level and able to maintain success, education transformation is the answer (MOE, 2012). This shows that education is an important tool towards producing quality human capital who will make the nation's vision a reality.

Therefore, various policies and transformation in education have been introduced by MOE and implemented in schools around the nation. In other words, school is an important organization that helps to produce future generation who will develop the nation to be a successful nation.

If the school is deemed the agent of change towards producing quality human capital for the nation, then, school climate is one very important factor that influences the change. Every school has its own unique school climate which differs one school form another. Halpin and Croft (1963), a pioneer in conducting a study in school climate viewed school 
climate as having an individual's characteristics. They also claimed that school climate portrays the personality of an individual and how that individual works towards achieving school success.

According to Hoy and Hoy (2006), school climate refers to school achievement. Najeemah (2012) claimed that a happy school is very motivated, with productive accomplishment which made it different from other schools. Howard (1974) defined school climate as a school's social environment and culture which influence the behavior of its community. This means that school climate plays an important role in influencing the behavior and achievement of the community in the school.

A healthy school climate is a school that focus on academic and the leader is able to influence the teachers and develop their belief that they have an impact on learning and teaching. Najeemah (2012) and Riechl \& Sipple (1966) claimed that the characteristics of a school may effect teachers' commitment.

Smith (2009) stated that teachers who obtain support from their leaders are more inclined to be committed to the vision and the mission of the school including the school values. Porter et al.,(1974) denoted commitment towards an organization as "a strong belief and acceptance of the aims and values, readiness to work diligently to represent the organization and clear desire to stay as the member of the organization". Schools that have dedicated teachers who are committed to the school will become effective schools. Peterson \& Skiba (2001) exclaimed that a school that have happy climate help in increasing teachers' commitment towards the school.

\subsection{Problem statement}

Schools are like 'factories' that produce harmonious and physically balanced human capital, so 'workers' in the 'factories' play very important role in the production line. Teachers who are highly dedicated and committed will complete their task to the best of their effort because they understand that they are the main player in the implementation of the curriculum.

Schools with positive climate will affect the behavior of the members. According to Halpin and Croft (1963), an effective school climate has characteristics such as: (1) the teachers feel secure, satisfied and confident, (2) the teachers are not pressured but always upkeep their students' development, (3) the principal is very confident and considerate, and (4) the students feel secure and study industriously.

Cohen (2006) stated that school climate affects its success. Previous researchers claimed that an organization climate affects the behavior of the organization members. Thus, school climate is said to also affect teachers' behavior. Therefore, teachers who are committed towards the teaching and learning process will affect the school's performance.

Hoy, Tarter, \& Kottkamp (1991) opined that effective teachers need high organization commitment and that students' high academic achievements need dedicated teachers. On the other hand, Abdul (2009) stated that students' excellent performance are related to high teachers' commitment towards the organization.

Education is a crucial item to develop and produce useful human capital to the nation, therefore schools with healthy and transparent climate will affect teachers' and students' behaviors towards achieving excellence for the school. There are various excellent schools all over Malaysia, such as Cluster School and High Prestige School. These types of school have succeeded in producing excellent human capital that are balanced physically, emotionally, spiritually and intellectually.

Ebrahim and Mohamadkhani (2014) conducted a study examining the importance of organization climate on teachers' involvement in schools and found that teachers' need conducive organization climate to encourage them to complete their tasks. At present, teachers are overburdened with clerical work besides their core business and this has discouraged them. The education transformation is taking a lot of teachers' time just to do the clerical work and this issue, if not addressed, will affect their interest to stay in the education line or they become less committed in their jobs. If the school climate is transparent and positive, teachers will feel comfortable doing their jobs with their colleagues; and if they have leaders who are considerate and give attention to the needs of the subordinates, teachers will be motivated because they know that they are fully supported especially when they are going through rough patches.

Reza Shirzadi, Jafar Ravan Shad, Mohammad Nasiri, Hasan Abdi and Shahrookh Khani (2013) claimed that by providing suitable or conducive climate at working place, the tendency to stay loyal and committed will increase. Malaysia is well known to have high vision towards producing quality human capital and schools are the agents for this goal. Therefore, school climate which can affect teachers' commitment is a study that should be endeavored. It is believed that teachers with high commitment will result in high performance students in all aspects especially in academic.

Therefore, it is crucial that the researcher examined the relationship between school climate of excellent schools and teachers' commitment. 


\subsection{Research Objectives}

The aim of this study was to examine the relationship between school climate and teachers' commitment in excellent schools in the district of Kubang Pasu, Kedah. Researchers wanted to see whether the climate of the schools being studied affected teachers' commitment. The objectives were to identify:

I. the level of school climate in excellent schools in the district of Kubang Pasu, Kedah.

II. the level of teachers' commitment in excellent schools in the district of Kubang Pasu, Kedah.

III. the relationship between school climate dimensions and teachers' commitment.

IV. the relationship between school climate and teachers' commitment.

V. the school climate dimensions that are most dominant in affecting teachers' commitment.

\subsection{Research Hypotheses}

Ho1: There is no significant relationship between collaborative leadership dimension and teachers' level of commitment.

Ho2: There is no significant relationship between teachers' professional behavior dimension and teachers' level of commitment.

$\mathrm{H}_{3}$ : There is no significant relationship between working pressure dimension and teachers' level of commitment.

Ho4: There is no significant relationship between institutional transparency dimension and teachers' level of commitment.

H05: There is no significant relationship between school climate and teachers' commitment.

\subsection{Limitation of Study}

This study was conducted in excellent schools only in the district of Kubang Pasu. Therefore, the findings could not represent all schools in Malaysia. Researchers could not be sure if the respondents have truly read through the questionnaire before responding to the items because teachers nowadays are already burdened with so many responsibilities besides teaching and they have very little time for themselves.

\section{Literature Review}

Halpin and Croft (1963) were the pioneer of the study for school climate. They deemed organization climate as a school's personality and the climate of a school has certain individual personality. Thus, the school climate of one school differs from another. In terms of organizations in educational environment, Tagiuri (1968), in Kelton, (2010) defined climate as the quality of the environment. Characteristics that are maintained for a certain period of time in schools is said to create the school climate and this creates the school personality which differentiate it from others. There are four dimensions in Tagiuri taxonomy of climate theory, namely:

a. Ecology : physical factors such as age, size and design of building; and technologies used in the organization.

b. Surroundings: refers to social dimension that relates the individuals to the organization, for example, ethnic groups, salary and level of education.

c. Social system: refers to social dimension that relates to the individuals' style of communication with the community in the organization.

d. Culture: refers to social dimension that relates to beliefs in the system, values, cognitive structure and also meaning.

Hoy, Tarter, and Koottkamp (1991) stated that school climate is the quality of the school surrounding or the school environment that is familiarized by the members of the school. These characteristics differentiate one school from another and affect the behavior of the members of the school. School climate affects the behavior, learning, productivity, and effectiveness, whereas the administration affects the school climate (Ali \& Hale, 2009; Azzara, 2001; Mine, 2009). This shows that if the school climate is not positive or conducive, then the members of the school will not be able to do their work efficiently. Workers who are committed to an organization are more inclined to work diligently, achieve good performance, work effectively and stay in the organization (Mowday, 1998).

Many researchers have conducted studies on teachers' commitment. Commitment refers to a teacher's willingness to contribute his/her energy and time towards his/her work. Portal et al. (1974) defined organization commitment as individual's willingness to identify and involve oneself in the organization. 
Najeemah (2012) has conducted a study to analyze the relationship between school climate and teachers" commitment. The population involved five primary schools in Penang, Malaysia. The finding showed that transparency of the institution level and teachers' commitment in the five schools were high. The correlation between school climate dimensions showed positive correlation with teachers' commitment. Regression analysis showed only teachers' professional behavior contribute towards teachers' commitment.

Wan (2011) has done a study titled "Correlation between intermediate leaders' instructional leadership practice and school climate, teachers' working attitude and organization commitment in secondary schools". This study aimed to identify the impact of intermediate leaders' instructional leadership practice such as Co-curriculum Senior Assistant and Department Heads on school climate, teachers' working attitude and organization commitment in secondary schools. 400 teachers from secondary schools in two northern states of Malaysia participated in this study. The result finding showed instructional leadership practice of intermediate leaders have significant relationship with teachers' working attitude and organization commitment. This study showed that instructional leadership practice of intermediate leaders was not influenced by the school performance. Meanwhile, through structured comparison model, it was found that teachers' working attitude and organization commitment have indirect relationship with inculcating positive learning climate and evaluating teachers' teaching program.

School climate is seen as a significant variable to determine teaching and learning process in schools. The finding of this study provides the base to develop a school leadership model which is robust in the context of teachers' professional development, teachers' productivity level and school performance. Based on the findings, some implications and suggestions have been made. Reza Shirzadi, Jafar Ravan Shad, Mohammad Nasiri, Hasan Abdi and Shahrookh Khani (2013) have conducted a descriptive study to identify the relationship between organization climate and work motivation with organization commitment among new teachers teaching Physical Education and training administration in Kermanshah. 196 respondents were selected at random to complete the questionnaire. The finding showed that there is positive significant relationship between organization climate and work motivation with organization commitment among new teachers teaching Physical Education and training administration. The researchers stated that providing good school climate and conducive working place for Physical Education teachers motivate them, increase their commitment and encourage them to stay in the organization.

Another study done by Collie, Shapka, and Perry (2011) about school climate and social- emotional learning led to prove that there is impact on teachers' commitment. The sample was 664 public school teachers in British Columbia and Ontario in Canada. The respondents completed the questionnaire online about teachers' commitment, school climate and social-emotional learning. The regression analysis showed that positive school climate indicates three types of teachers' commitment that are; general professional commitment, future professional commitment and organization commitment. Douglas (2010) also conducted a study to identify the relationship between school climate and teachers' commitment at primary schools in Alabama. There were 67 primary schools and 1353 teachers participated as respondents. The finding showed that there is relationship between school climate and teachers' commitment. Teachers' professional behavior is the best commitment indicator. Collaborative leadership also is another indicator that influences teachers' commitment. Academic pressure although did not show influence on teachers; commitment, it showed impact on teachers' professional behavior and collaborative leadership. Institutional transparency has no direct relationship with teachers' commitment. Smith (2009) also conducted the study in 34 primary schools in the northern part of Alabama whereby 522 teachers participated. It showed the same result and the best indicator for teachers' commitment was teachers' profession. Collaborative leadership and academic pressure were the indicators in teachers' profession.

\section{Research Methodology}

\subsection{Population}

Teachers teaching in primary schools in the district of Kubang Pasu, Kedah were selected as participants. The reason for choosing Kubang Pasu district was based on the 2013 UPSR result whereby this district obtained the best result compared to the other eight districts in Kedah. There were 5 primary schools who attained academic excellence in 2013 and they were Sekolah Kebangsaan Sultan Ahmad Tajuddin, Sekolah Kebangsaan Jitra 3, Sekolah Kebangsaan Darulaman Height, Sekolah Kebangsaan Telok Malek, and Sekolah Kebangsaan Bandar Baru, Darulaman. These schools were selected because the researchers wanted to examine the characteristics of school climate in these schools that have increased the teachers' commitment and influenced the students' academic performance. Besides that, it will be beneficial if this district can be a model district for other schools in Kedah. All the five excellent schools produced a total of 280 teachers. To determine the number of required sample, a formula created by Krejcie and Morgan (1970) was 
used, $s=X^{2} N P(1-P) \div d 2(N-1)+X^{2} P(1-P)$, where :

$\mathrm{S}=$ required sample size

$\mathrm{X}^{2}=$ the table value of chi-square for 1 degree of freedom at the desired confidence level (3.841)

$\mathrm{N}=$ population size

$\mathrm{P}=$ ratio of population (assumed as .50 as this will give maximum sample size).

$\mathrm{d}=$ the degree of accuracy expressed as a proportion (.05)

Based on this formula, the desired sample to complete this study was 162 teachers. 250 sets of questionnaire were distributed to ensure a good return rate .

\subsection{Research Instrument}

The questionnaire is divided into three sections; section A is teachers' demography with 2 items, section B is the Organizational Climate Index $(\mathrm{OCl})$ that consists of 4 school climate dimensions adapted from Hoy et al. (2002) with 28 items. Section C has 28 items adapted from Celep (2000) that relates to teachers' commitment in school to measure organization commitment.

\subsubsection{Section A : Teachers' Demographic Information}

This section contains information such as teachers' gender and teaching experience.

\subsubsection{Section $B: O C l$}

This instrument, adapted from Hoy et al. (2002) contains 27 items to examine school climate and school transparency. There are 4 dimensions which measure collaborative leadership, teachers' professional behavior, work pressure and institutional transparency. The instrument used 4-point Likert scale that denotes 1-'seldom occurs' to 4- 'very often occurs'. Hoy et al. (2002) in his study, has conducted reliability test item on this instrument and the reliability index for all 4 dimensions were as follows: collaborative leadership (.94), teachers' professional behavior (.88), work pressure (.92), and institutional transparency (.87).

\subsubsection{Section C: Teachers Organizational Commitment}

This instrument was adapted from Celep (2000) to measure teachers' organizational commitment. This section contains 28 items which were divided into 4 dimensions. The first dimension consists of 9 items (1-9) examined teachers' commitment towards school. The second dimension, with 6 items $(10-16)$ examined teachers' commitment towards teaching task. The third dimension looked at teachers' commitment towards the teaching profession and contained 6 items $(17$ - 22). The last dimension with 6 items $(23-28)$ was to examine teachers' commitment towards teamwork. 5point Likert scale was used with 5 to denote 'very high' and 1 as 'very low'. Celep (2000) has conducted reliability test item and the reliability index for all 4 dimensions were as follows: teachers' commitment towards school (.80), teachers' commitment towards teaching task (.75), teachers' commitment towards the teaching profession (.78) and teachers' commitment towards team work (.81). The overall reliability index was (.88).

\section{Research Findings}

The respondents for this study were teachers from 5 primary schools which attained excellent results in academics in 2013. They were Sekolah Kebangsaan Sultan Ahmad Tajuddin, Sekolah Kebangsaan Jitra 3, Sekolah Kebangsaan Darul Aman Height, Sekolah Kebangsaan Telok Malek and Sekolah Kebangsaan Bandar Baru, Darul Aman. The desired sample was 162 and the researchers have distributed 250 questionnaires randomly to the selected schools. 178 were returned with a return rate of $71.2 \%$.

\subsection{Distribution of Respondents based on Gender}

Descriptive analysis was used to explain respondents' information in terms ofgender and teaching experience. Based on Table 1, 30 respondents were male teachers (16.9\%) and 148 were female teachers (83.1\%). 
Table 1: Distribution of Respondents based on Gender.

\begin{tabular}{ccc}
\hline Gender & Number & Percentage \\
\hline Male & 30 & 16.9 \\
Female & 148 & 83.1 \\
\hline Total & 178 & 100.0 \\
\hline
\end{tabular}

\subsection{Distribution of Respondents based on Teaching Experience}

Table 2 below showed that 13 respondents have 1 to 5 years of teaching experience whereas 46 respondents have more than 20 years of teaching experience. 40 teachers with teaching experience between 6 and 10 years, 34 teachers between 11 and 15 years and 45 teachers with 16 and 20 years of teaching experience.

Table 2: Distribution of Respondents based on Teaching Experience

\begin{tabular}{ccc}
\hline Years of Teaching Experience & Number & Percentage \\
\hline $1-5$ & 13 & 7.3 \\
$6-10$ & 40 & 22.5 \\
$11-15$ & 34 & 19.1 \\
$16-20$ & 45 & 25.3 \\
$>20$ & 46 & 25.8 \\
\hline Total & 178 & 100 \\
\hline
\end{tabular}

\subsection{School Climate in Excellent Primary Schools in Kubang Pasu District.}

\subsubsection{Research Question (1) :-}

What is the level of school climate in excellent schools in the district of Kubang Pasu, Kedah?

Descriptive analysis was used to obtain the overall mean value for each climate dimension followed by comparing the overall mean with mean interpretation to determine the level of climate in the excellent schools in the 2013. The overall mean value is presented in Table 3 below. The finding showed that the mean value for all the dimensions were averagely high; collaborative leadership dimension (3.29), teachers' professional behavior (3.45), work pressure (3.19), and institutional transparency (2.40). The overall mean value of school climate for the 5 schools was 3.14.

Table 3: Mean and Standard Deviation for School Climate

\begin{tabular}{ccc}
\hline School Climate Dimension & Mean & Standard Deviation \\
\hline Collaborative Leadership & 3.29 & 0.50 \\
Teachers' Professional Behavior & 3.45 & 0.45 \\
Work Pressure & 3.19 & 0.40 \\
Institutional Transparency & 2.40 & 0.75 \\
\hline Overall & 3.14 & 0.34 \\
\hline
\end{tabular}

\subsection{Teachers' Commitment Level in Excellent Schools in Kubang Padu District.}

\subsubsection{Research Question (2) :-}

What is the level of teachers' commitment in excellent schools in the district of Kubang Pasu, Kedah?

To address this question, the researchers have used descriptive analysis to obtain the overall mean value for each teachers' commitment dimension, followed by comparing the overall mean with mean interpretation to determine the level of teachers' commitment in excellent schools in Kubang Pasu District. The finding (Table 4) showed an overall of high mean value for all the dimensions (4.08); commitment towards the school (3.88), commitment towards teaching tasks (4.17), commitment towards the teaching profession (4.20) and commitment towards team work (4.15). 
Table 4: Mean and Standard Deviation for Teachers' Commitment

\begin{tabular}{lcc}
\hline Commitment Dimension & Mean & Standard Deviation \\
\hline Commitment towards School & 3.88 & 0.45 \\
Commitment towards teaching tasks & 4.17 & 0.47 \\
Commitment towards the teaching profession & 4.20 & 0.48 \\
Commitment towards team work & 4.15 & 0.51 \\
\hline Overall & 4.08 & 0.39 \\
\hline
\end{tabular}

\subsection{Normality Test}

Shapiro - Wilk (W) test was .970 ( $p<.05)$ for school climate. However for teachers' commitment, Shapiro - Wilk (W) test was $.975(p<.05)$. Therefore, it can be said that the data tested were not from a normally distributed population.

Thus, to examine the relationship between school climate and teachers' commitment, the researchers used Spearman's rank test to measure non-parametric data.

\subsection{Hypotheses Testing H01 hingga H05}

To examine the relations between climate dimensions with teachers' commitment, researchers employed Spearman's rho correlation test. This test was used to identify linear relationships between two research variables that are school climate dimensions and teachers' commitment. The correlation value is as presented in Table 5 below:-

Table 5: Correlation value Interpreted according to Hinkle, Wiersma and Jurs (1988)

\begin{tabular}{cc}
\hline Correlation Value & Relationship Strength \\
\hline $\pm 0.90-1.00$ & Very Strong \\
$\pm 0.70-0.90$ & Strong \\
$\pm 0.50-0.70$ & Averagely Strong \\
$\pm 0.30-0.50$ & Weak \\
$\pm 0.01-0.30$ & Very Weak \\
0 & No relationship \\
\hline
\end{tabular}

Table 6 showed the relationship between collaborative leadership dimension and teachers' commitment.

$\mathrm{H}_{0} 1$ : There is no significant relationship between collaborative leadership dimension in school climate and level of teachers' commitment.

Based on correlation analysis of Spearman Test, it is found that the relationship between collaborative leadership dimension and teachers' commitment is positive and significant statistically $(r=.51, p<.05)$.

Table 6 : Spearman Correlation between Teachers' Collaborative leadership Dimension and Teachers' Commitment

\begin{tabular}{ccc}
\hline Variables & $\begin{array}{c}\text { Teachers' Commitment } \\
\text { Correlation Value }(r)\end{array}$ & Significant \\
\hline Collaborative leadership & $.51^{* *}$ & .00 \\
\hline Significant at 0.01 & &
\end{tabular}

This result rejected $\left(H_{0} 1\right)$. The positive significant relationship showed that a high collaborative leadership dimension can increase the level of teachers' commitment and vice versa. Collaborative leadership dimension in school climate has average positive relationship $r=.51$.

Ho2: There is no significant relationship between teachers' professional behavior dimension in school climate and level of teachers' commitment.

Based on correlation analysis in Table 7, it is found that the relationship between teachers' professional behavior dimension in school climate and level of teachers' commitment is positive and significant $(r=.52, p<.05)$. This result rejected (Ho2). The positive significant relationship showed that a high teachers' professional behavior dimension in school climate can increase the level of teachers' commitment and vice versa. Teachers' professional behavior dimension 
in school climate has average positive relationship $r=.52$.

Table 7: Spearman Correlation between Teachers' Professional Behavior Dimension and Teachers' Commitment

\begin{tabular}{ccc}
\hline \multicolumn{1}{c}{ Variables } & $\begin{array}{c}\text { Teachers' Commitment } \\
\text { Correlation Value }(r)\end{array}$ & Significant \\
\hline Teachers' Professional Behavior & $.52^{2 *}$ & .00 \\
\hline${ }^{* *}$ Significant at 0.01 & &
\end{tabular}

Ho3: There is no significant relationship between work pressure dimension in school climate and level of teachers' commitment.

Table 8 showed that the relationship between work pressure dimension in school climate and level of teachers' commitment is positive and significant $(r=.42, p<.05)$. This result rejected (Ho3). Overall, the correlation result showed the low $r$ value but significant because of the large sample size. The positive significant relationship showed that a high work pressure dimension in school climate can increase the level of teachers' commitment and vice versa. Work pressure dimension in school climate has low positive relationship $r=.42$.

Table 8: Spearman Correlation between Work Pressure Dimension and Teachers' Commitment

\begin{tabular}{ccc}
\hline Variables & $\begin{array}{c}\text { Teachers' Commitment } \\
\text { Correlation Value }(r)\end{array}$ & Significant \\
\hline Work Pressure & $.42^{* *}$ & .00 \\
\hline${ }^{*}$ Significant at 0.01 & &
\end{tabular}

Ho4: There is no significant relationship between institutional transparency dimension in school climate and level of teachers' commitment.

Table 9 showed no relationship between institutional transparency dimension in school climate and level of teachers' commitment $(r=.009, p>.05)$. This result failed to reject $(\mathrm{Ho4})$.

Table 9: Spearman Correlation between Institutional Transparency Dimension and Teachers' Commitment

\begin{tabular}{ccc}
\hline Variables & $\begin{array}{c}\text { Teachers' Commitment } \\
\text { Correlation Value }(\mathbf{r})\end{array}$ & Significant \\
\hline Institutional Transparency & $.009^{* *}$ & .90 \\
\hline Significant at 0.01 & &
\end{tabular}

Ho5: There is no significant relationship between school climate and teachers' commitment.

Table 10 showed that there is positive significant relationship between school climate and teachers' commitment ( $r$ $=.52, \mathrm{p}<.05)$. This result rejected ( $\mathrm{Ho5})$. The positive significant relationship showed that a high school climate dimension can increase the level of teachers' commitment and vice versa. School climate dimension has average positive relationship $r=.52$. School climate was $R 2=.27$ which showed that school climate contributed $27 \%$ variants related to teachers commitment variants.

Table 10: Spearman Correlation between School Climate and Teachers' Commitment.

\begin{tabular}{ccc}
\hline Variables & $\begin{array}{c}\text { Teachers' Commitment } \\
\text { Correlation Value }(r)\end{array}$ & Significant \\
\hline School Climate & $.52^{* *}$ & .00 \\
\hline * Significant at 0.01 & &
\end{tabular}

Spearman Correlation test was conducted on each school climate dimension with teachers' commitment. Based on the findings, it was found that teachers' professional behavior dimension showed a high correlation value $r=.52$ compared to other dimensions. Meanwhile, collaborative leadership dimension showed value $r=.51$. both dimensions showed $\mathrm{R}^{2}=.26$ and $\mathrm{R}^{2}=.27$ consecutively. This proved that both teachers' professional behavior and collaborative leadership 
dimensions contributed $26 \%$ and $27 \%$ variants related to teachers' commitment variants.

Table 11 showed the overall result findings of Spearmen Correlation test for each school climate dimension with teachers' commitment.

Table 11: Spearmen Correlation test for each school climate dimension with teachers' commitment.

\begin{tabular}{lcc}
\hline Teachers' Commitment Dimension & Correlation Value $(r)$ & Significant \\
\cline { 2 - 3 } Collaborative Leadership & $.51^{\star *}$ & .00 \\
Teachers' Professional Behavior & $.52^{\star *}$ & .00 \\
Work Pressure Dimension & $.42^{\star *}$ & .00 \\
\hline
\end{tabular}

\section{Discussion}

The researchers conducted this study to identify the level of school climate in the excellent schools and the relationship between school climate and teachers' commitment which is believed to have contributed to the academic excellence of the schools in the district of Kubang Pasu.

\subsection{The level of School Climate in Excellent schools in the Kubang Pasu District}

The level of school climate in all the five excellent schools is averagely high based on the descriptive statistic result. The result showed that school climate of a school does affect the school's performance. This result is similar with the study result by Mohsen, Mohammad, Naghi and Sayed (2014). They have also found that school organizational health has significant effect on academic performance.

This finding of this study also supported the result finding by Mahdieh, Syed, and Koroush (2013) which found that positive climate resulted from efficient management of the organization to be one of the factors that should be deliberated so as to achieve excellent academic results. The result of this study is similar to the study conducted by Siti Noor Binti Ismail (2011) which found that the level of school climate in high prestige schools is very high.

The finding of this study is also in concordance with the study conducted by Smith, Hoy and Sweetland (2003). Their findings showed that there is positive relationship between school climate and students' achievement. This means that the students' academic achievement will be good if the school climate is positive and good. This study has shown that school climate affects school performance. According to Hoy and Hoy (2006), this is due to the fact that school climate relates to school performance. Najeemah (2012) stated that a happy school is a school that is highly motivated with productive achievements and which makes the school different from other schools.

\subsection{The level of Teachers' Commitment in Excellent Schools in the Kubang Pasu District}

Referring to the descriptive statistic result, we can see that the overall mean score for teachers' commitment is high (mean=4.08). The high level of teachers' commitment is believed to be one of the factors that affects the schools' performance. According to Najeemah (2012), committed teachers have strong psychological bond with the school, students and their subjects. Therefore, teachers with high commitment towards school will work diligently which will result in the increase of students' performance.

This finding is similar to the one done by Madhu Gupta and Manju Gehlawat (2013) who found that organizational commitment is an important factor which contribute to an effective education system. Teachers who are highly committed towards school are easily motivated and they perform their teaching tasks voluntarily. According to Rathod (2013), committed teachers make a difference in school success and students' learning. Highly committed teachers has been identified as one of the important factors that contributes to the future of schools and education as shown by the teachers in the five excellent schools in the Kubang Pasu District.

\subsection{Relationship between School Climate and Teachers' Commitment}

Four school climate dimensions (collaborative leadership, teachers' professional behavior, work pressure and institutional transparency) were examined to see the relationship between the dimensions and teachers' commitment. Based on the Spearman Correlation Test, the researchers found that collaborative leadership has positive average relationship $r=.51$ with teachers' commitment. For teachers' professional behavior dimension, the relationship with teachers' commitment is positively average too $r=.52$. Work pressure dimension has low positive relationship $r=.42$ whereas there is no 
relationship between institutional transparency and teachers' commitment found in this study. This finding is similar to the finding by Douglas (2010) who found that collaborative leadership, teachers' professional behavior and work pressure have relationship with teachers' commitment whereas institutional transparency has no relationship with teachers' commitment.

Najeemah (2012) stated that correlation between collaborative leadership dimension, teachers professional behavior, work pressure and also institutional transparency were positive with teachers' commitment. Most of the result findings are similar with the study conducted. The only difference is the finding of this study showed that no relationship exists between institutional transparency and teachers' commitment.

\subsection{Relationship between School Climate and Teachers' Commitment}

This study showed that there is positive significant relationship between school climate and teachers' commitment. This proved that high level of school climate eill result in high level of teachers' commitment and vice versa. This finding is in concordance with the result by Reza et.al.,(2013) which found that there is positive significant relationship between organizational climate and work motivation with organizational commitment among Physical Education teachers who are new to the education and management training. The researchers claim that physical education teachers' motivation and level of commitment will increase if they are provided with good school climate and conducive work place. By providing good school climate and conducive working place for physical education teachers will motivate them. This will also make them loyal to the school.

The result finding which proved that there is relationship between school climate and teachers' commitment is similar to the study by Douglas (2010) and Smith (2009). The result of this study showed that there is relationship between collaborative leadership, teachers' professional behavior and work pressure dimensions; and teachers' commitment. Since school climate is related to teachers' commitment, it is vital that all schools in Malaysia create harmonic and conducive organizational climate so as to increase teachers' commitment and thus increase school performance.

\subsection{School Climate Dimension that displays most dominant relationship towards teachers' commitment.}

The finding of this study showed that teachers' professional behavior and collaborative leadership dimensions each contributed $26 \%$ and $27 \%$ variants that relate to teachers' commitment variants. The correlation value for each is $r=.52$ and $r=.51$ consecutively. Based on both values it can be concluded that teachers' professional behavior and collaborative leadership dimensions have dominant relationship towards teachers' commitment but teachers' professional behavior dimension is proved to have the most dominant relationship towards teachers' commitment. This result coincides with finding by Douglas (2010) who stated that both teachers' professional behavior and collaborative leadership dimensions are the predictor of teachers' commitment.

Studies conducted by Najeemah (2012) and Smith (2009) found that only teachers' professional behavior was the predictor of teachers' commitment, and collaborative leadership, work pressure and institutional transparency failed to be the predictors of teachers' commitment.

Teachers' professional behavior refers to show of respect towards colleagues' competency, commitment towards the students, autonomy assessment, cooperation and support between colleagues (Hoy, Smith, \& Sweetland, 2002). Respect towards colleagues and collaborative work will create harmonic working environment. Teachers who are helpful, magnanimous in sharing knowledge especially in the learning and teaching process will produce colleagues or members of the organization who are united. This will motivate the members of the organization to work harder or become more committed towards the school. On the other hand, if members of the organization are self-centered or uncooperative, there will be no unity nor enjoyment in working. This will demotivate the teachers to do their jobs well (Najeemah, 2012).

\section{Conclusion}

In conclusion, the Ministry and related stake holders should not ignore school climate which has been proven to have effect on teachers' commitment. The Ministry should make sure that schools have conducive environment by providing sufficient funds to increase the physical climate of the schools. Teachers' motivation and commitment will increase when they work in a secured and comfortable place, fully equipped with teaching aids such as computers. Besides, the Ministry should also provide opportunities for school leaders to attend workshops or courses that can increase their leadership styles or practices so that school excellence and the education vision can be achieved. 


\section{References}

Abdul, S. J. M. A. R. (2009). The level of commitment and its relation to students' achievement as perceived by English Language teachers in public schools in Tulkarm district. Tesis Master. An-Najah National University, Nablus, Palestine.

Ali, E., \& Hale, E. (2009). Predicting organizational trust level of school managers and teachers at elementary schools. Procedia-Social and Behavioral Sciences, 1(1), 2180-2190.

Azzara, J. R. (2001). The heart of leadership. Educational Administration, 58(4), 62-64.

Abdul, S. J. M. A. R. (2009). The level of commitment and its relation to students' achievement as perceived by English Language teachers in public schools in Tulkarm district. Tesis Master. An-Najah National University, Nablus, Palestine.

Cohen, J. (2006). Social, emotional, ethical, and academic education : creating a climate for learning, participation in democracy, and well-being. Harward Educational Review, 76(2), 201-237.

Collie, R. J., Shapka, J. D., \& Perry, N. E. (2011). Predicting teacher commitment : the impact of school climate and social-emotional learning. Psychology in The Schools, 48(10), 1034-1048.

Douglas, S. M. (2010). Organizational Climate and Teacher Commitment. Tesis Ph.D. The University of Alabama. Tuscaloosa, Alabama.

Ebrahimi M. \& K. Mohamadkhani. (2014). The relationship between organizational climate and job involvement among teachers of high schools in Delijan City (Iran). International Journal of Management and Business Research, 4(1), 65-72.

Gupta, M. \& Gehlawat, M. (2013). A study of the correlates of organizational commitment among secondary school teachers. Issues and Ideas In Education, 1(2013), 59-71.

Halpin, A. W., \& Croft, D. B. (1963). The organizational climate of schools. Danville, IL: Interstate Printers and Publishers, Inc.

Howard, E.R. (1974). School climate improvement. Education Digest 39 (8): 333-336

Hoy, A. W., \& Hoy, W. K. (2006). Instructional leadership: A research-based guide to learning in schools 2nd edition. Boston: Allyn and Bacon.

Hoy, W. K., Smith, P. A., \& Sweetland, S. R. (2002). The development of the organizational climate index for high schools: its measure and relationship to faculty trust. High School Journal, 86(2), 38.

Hoy, W. K., Tarter, C. J., \& Kottkamp, R. B. (1991). Open schools, health schools. Newbury Park: Sage Production.

Kelton, K. E. (2010). A study of the comparison between teacher perceptions of school climate and the existence of professional learning community dimensions.Tesis Ph.D. University of Central Florida. Orlando, Florida.

Krejcie, R. V. dan Morgan, D. W. (1970). Determining sample size for research education and psychological measurement. Education and Psychological Measurement. 3. 607-610.

Mahdieh Mashayekhi, Seyed Ahmad Nejad Sajjadi \& Koroush Ghahraman Tabrizi. (2013). The relationship between organizational climate school and job involvement of physical education teachers. Switzerland Research Park Journal. 102(10), 962-968.

Ministry of Education. (2006). Malaysian Education Blueprint 2006-2010. Edisi Pelancaran. Kuala Lumpur: Percetakan Nasional Berhad

Ministry of Education. (2012). Malaysian Education Blueprint 2013 - 2025. Kuala Lumpur: Percetakan Nasional Berhad

Mine, S. (2009). Leadership behaviors of school principals in relation to teacher job satisfaction in north Cyprus. Procedia-Social and Behavioral Sciences, 1(1), 2855-2864.

Mohsen F. F., Mohammad H. M., Naghi R.A., Sayed S.M. (2014). The study of the relationship of organizational health of the schools and that of the student's academic achievement (A case study of high school of Kohkilouie and Boierahmad Province, Iran 2011). Procedia - Social and Behavioral Science,109 (2014), 628-633

Mowday, R. T. (1998). Reflections on the study and relevance of organizational commitment. Human Resource Management Review, 8(4), 387-401. Tesis Ph.D, Northeastern University.

Najeemah M. Y (2012). School climate and teachers ' commitment: a case study of Malaysia. International Journal of Economics Business and Management Studies, 1(2), 65-75.

Peterson, R. \& Skiba, R. (2001). Creating School Climates that Prevent School Violence. Preventing School Failure, 44(2), $122-130$.

Porter, L. W., Steers, R. M., Mowday, R.T., \& Boulian, P. V. (1974). Organizational commitment, job satisfaction, and turnover among psychiatric technicians. Journal of Applied Psychology, 59(5), 603-609

Rathod Mahipalsinh Vikraminsh (2013). Teacher's work commitment for school and students. An International Multidisciplinary Peer Reviewed \& Journal. 2(6), 341-347.

Reza, S., Jafar, R. S., Mohammad, N., Hasan, A. \& Shahrookh, K. (2013). The relation of organizational climate and job motivation with organizational commitment of new employed teachers of physical education of educations and training administration in Kermanshah Province. Advances in Environmental Biology. 7(13), 4084-4088.

Riehl, C., \& Sipple, J. W. (1996). Making the most of time and talent: Secondary school organizational climates, teaching task environments, and teacher commitment. American Educational Research Journal, 33, 873-901.

Siti Noor Binti Ismail. (2011). Hubungan antara amalan pengurusan kualiti menyeluruh (TQM) dengan iklim sekolah dalam kalangan sekolah-sekolah menengah berprestasi tinggi, sederhana dan rendah di negeri Kelantan. Tesis Ph. D, Universiti Utara Malaysia.

Smith, L. D. (2009). School climate and teacher commitment. Tesis Ph. D. The University of Alabama.

Smith, P. A., Hoy, W. K., \& Sweetland, S. R. (2003). Organizational health of high schools and dimensions of faculty trust. Journal of School Leadership, 11, $135-150$.

Wan Roslina, W. I. (2011). Korelasi amalan kepemimpinan pengajaran pemimpin pertengahan dengan iklim sekolah, sikap kerja guru dan komitmen organisasi di sekolah menengah kebangsaan. Tesis Ph.D. Universiti Utara Malaysia. 